\title{
Democratising Terai Forestry Governance: Emerging Innovations in the Western Terai Region of Nepal
}

\author{
Bal Krishna Jamarkattel*, Sindhu Prasad Dhungana*, Srijana Baral**, Bishwas Rana* and Hari \\ Dhungana*** \\ * Livelihoods \& Forestry Programme (LFP), Nepal \\ **Freelance Forester \\ $* * *$ ForestAction Nepal \\ Corresponding author: jkbalkrishna@yahoo.com
}

\begin{abstract}
The Government of Nepal has had a high interest in the Terai forest in order to harness its enormous revenue potential. However, the policies and plans formulated to this end have not attained the intended results, as these have failed to fully understand the emerging complexities in the Terai. Accordingly, policy response has often been ad hoc, inconsistent and unstable, leading to confusion and conflict on Terai forest management. Drawing on the cases of three districts of Lumbini zone in the Western Terai of Nepal, this paper discusses the forest management context of Nepal Terai, and identifies key innovations that have emerged at district and local levels. It argues that these innovations have the potential for a creative transformation of forest management planning process at district and local level, and for their wider replication and diffusion. This paper also discusses key issues that need further attention so as to maximise the impact of these innovations by putting them into practice. It highlights that emerging complexity of Nepal Terai requires much wider stakeholder engagement in order to facilitate forest management planning and implementation that benefit both the government and the people.
\end{abstract}

Key words: forest management, democratisation, participatory planning, DFCC, Terai forestry

\section{INTRODUCTION}

The extensive natural forest of Nepal's Terai has received high attention from diverse stakeholders ranging from grassroots to the national and international levels. Potentials of its management have been well recognised and successive governments have made various efforts to realise them. However, these efforts have not proved successful throughout the history (Bampton et al. 2007). Though national forests under community management are well conserved in most of the cases, productive and sustainable management of those forests is still lacking. Shortcomings of Community Forestry (CF) and controversies over different contested management modalities have hindered forest management interventions, resulting in large tracts of potentially productive forest under or over utilised (Pravat 2006). Particularly, the debate of CF versus Collaborative Forest Management (CFM) has become too polarised for both sides to compromise for overall sustainable forest management (Bampton
2006). Therefore, Terai forestry has been debated for many years (Rai 2007) with new and complex issues emerging with the passage of time. Moreover, Terai forest is under enormous pressure as it has to nurture for almost half of the country's population (11.2 million as per CBS 2005) residing locally and has to supply forest products to the major cities in the hills and valleys of the country. Deforestation is still a problem as annual rate of deforestation in the region outside the protected areas is 0.08 percent which is the result of illegal felling and encroachments. Such activities have been found particularly in the forests which have not been brought under any defined management modalities, although they are simplistically categorised as Government Managed Forest (GMF) by forest laws.

At this point, it is important to reflect on the government's past policies, their ground level responses, and their implications for the future. The paper builds on the authors' working experience in the Terai forestry and analyses 
information obtained through a stakeholder survey, literature review and secondary information from Nawalparasi, Rupandehi and Kapilvastu districts in Western Terai. At first, this paper briefly outlines the context of Terai forestry and reviews the key policy interventions and their responses. Secondly, it identifies and discusses a number of innovations in Terai forestry that corresponds to institutional mechanisms and multi-stakeholder engagement, which collectively aim at ensuring equity, inclusiveness and participation. This paper then discusses the issues of and implications for the replication and diffusion of these innovations. Some conclusions are then drawn from the adoption of these innovations and issues confronted so far.

\section{TERAI FORESTRY CONTEXT}

\section{Terai Forest and its Importance}

The Terai of Nepal is the low, flat land lying mainly to the south of the Siwalik Hills. It extends from east to west along the country and covers approximately 20 percent of the country's land area. Total forest cover (including protected areas) in the twenty Terai districts is 41.5 percent (i.e. 1.4 million ha) of the land area. Altogether 57 percent of the forest area in the 20 Terai districts is found in the Churia or Mahabharat hills, leaving only 43 percent $(493,379 \mathrm{ha})$ in the Terai plains or inner Terai plains (Bampton et al. 2007).

Part of the area is designated under the Protected Area system. The forests outside the protected areas including buffer zones have been classified into five management categories: community forest, government managed forest, protection forest, leasehold forest and religious forest. Although Terai forest makes up approximately one-fourth of the national forests, only about three percent of it have been handed over to local communities as community forests and approximately 15 percent of the Community Forest User Groups (CFUGs) (around 2000 in number) are in the Terai (Pokharel et al. 2007). As the area managed as leasehold and religious forests is insignificant as compared to the total forest area, major parts of the national forest is still under GMF. However, some part of the GMF has been initiated to be managed as Collaborative Forest Management in recent years.

The Terai has been identified as the region with the greatest immediate economic potential for the forestry sector in Nepal (Mitchell 2001 cited in Pravat 2006). It has been a prime source of government revenue from as early as the $18^{\text {th }}$ century (Pravat 2006). Empirical analyses show that Terai forests have potential to produce benefit-cost ratio as much as 7:1 under wellmanaged community forests (Dhungana 2007). Besides economic value, the forest is an important resource in terms of ecology, culture and recreation. Ojha (2008) has highlighted the opportunity, and social and ecological costs of not properly managing the Terai forests. Thus the management of the Terai forests is a matter of concern for the diverse stakeholders, including the government officials, local communities, encroachers, contractors, and the Timber Corporation of Nepal (TCN).

\section{Policy Interventions on Terai Forestry and their Responses}

A number of policy interventions have been attempted to manage and use Terai forest resources since long back, albeit with contested responses and impacts. During the Rana regime, an agreement between the Government of Nepal (GoN) and then East India Company was made to export Sal timber from Terai forest to India (Dhungana 2007). Similarly, establishment of timber depots in 1950s and TCN in 1959 were the initiatives primarily focused on extraction of forest products from the country. In the late 1970s, the government prepared and implemented a scientific management plan called Sagarnath Forest Development Project ${ }^{1}$ in central Terai with an aim to supply fuelwood to meet local demands. The World Bank-funded Terai Community Forestry Development Project was also launched in the early 1980s with programs to afforest canal-banks, barren riversides, waste lands and private lands in the Terai. However, the project basically failed to 
find an alternative way to sustainable forestry (Baral 2002). During the nineties, attempts were made to manage Terai forest through Operational Forest Management Plan (OFMP). The attempts were never fully implemented primarily due to the lack of local peoples' participation and adequate funding by the central government (Baral 2002, Dhungana 2007, Rai 2007). Further, a scientific forest management plan prepared for Bara district could also not be implemented due to lack of public support.

National Forest Plan 1976 and subsequent Panchayat Forest and Panchayat Protected Forest Rule in 1978 opened the door for community based forestry. The Master Plan for Forestry Sector 1989, Forest Act 1993 and Forest Regulations 1995 provided for the handover of state-owned forest to local communities. The Forest Sector Policy 2000 paid high attention to the management of Terai forests and introduced the concept of Collaborative Forest Management (CFM). It was followed by the CFM guideline 2003. In addition, there are different decisions, circulars and informal directives regarding the management of Terai forests. Government's three-year interim plan (20082011) recognises the issue of distant users and also encourages the involvement of all party committees at local level in order to carry out forestry programmes. This plan aims to prepare district forestry sector plans basically to bring consensus among diverse stakeholders at district level to develop sector-wise strategy and vision for well-managed forests. Guideline for DFCC 2005 allowed the creation of DFCCs as a forum for multi-stakeholder coordination and decision-making (MFSC 2005). However, contradictory provisions between forestry laws and Local Self Governance Act 1999 have been issues to be resolved for better understanding among the local stakeholders regarding the local level forestry sector governance.

\section{Forestry in Three Western Terai Districts}

The study is based on the three districts in western Terai, viz. Nawalparasi, Rupandehi and Kapilvastu, which have been supported by DFIDfunded Livelihoods and Forestry Programme since 2001 and will be continued till 2011. The three districts altogether cover 185,392 ha of forests. Forest encroachment has been a continual problem in all three districts. Only about eight percent of the total population of the districts are confined to the new settlements in the northern parts, where majority of the national forests lie. On the other hand, majority of the Terai population (around 80 percent) lives in the southern part and lack direct access to the forest resources. This situation has fuelled a tension over the use of forest resources in the area (Dhungana 2007). Although, few modalities such as community forests have been comparatively more effective than others, there are several modalities at least in a token scale in the study sites, which are briefly discussed below.

Community Forestry: Community Forestry is the main community-based forest management modality in the region. The recent data shows that only $16,457.15$ ha of total national forest has come under this management modality benefitting 151 CFUGs with 76,651 households. It directly serves nearly one-fourth (23.8 percent) population of the districts. Though the target identified by the OFMPs is almost reached, still the recent 5 year District Forestry Sector Plan (DFSP) has prioritised 76,499 ha of forests area as Potential CF. This implies that there will be a very high scope for CF promotion in the area.

Government Managed Forest: Almost 88 percent of the Terai forests are under the government management scheme. These forests are rarely managed scientifically in practice even in demonstration plots ${ }^{2}$. In GMF, the management practices are still traditional in nature. The practice of forest patrolling is still going on without doing any assessment on 
whether it would work (Baral 2002). The GMF practices are no more than confiscation of illegally collected forest products or the removal of dead, dying and fallen trees through annual harvesting quotas assigned to DFO, the TCN or the District Forest Product Supply Board (DFPSB) (Acharya et al. 2006 cited in Bampton and Cammaert 2007).

Collaborative Forest Management: Following the Revised Forestry Sector Policy 2000 and the CFM guidelines 2003, a part of GMF which are in large contiguous blocks, have been identified to be managed under collaborative mode. The CFM is appreciated by local stakeholders for its equity perspective and for addressing the needs of distant users in principle (Bampton et al. 2007). But, there are more issues in practice to be resolved for its effective implementation. Opponents of the CFM system argue that CFM has been initiated to halt community forestry in the dense forests and limit them in the scattered patches. Until November 2008, only one CFM group ${ }^{3}$ has been formalised even with the years of work in the three districts. However the recently updated district forest management plan delineated a total of 36,142 ha forests under potential CFM. Preliminary estimation shows that efforts have been initiated to manage approximately 10,000 hectares of block forests under CFM in Fiscal Year 2008/09 in the three districts.

Leasehold Forestry: Though there is only one poor focussed leasehold forest in Kapilvastu and an industrial leasehold forest in Rupandehi district, leasehold forestry for the poor has been intensively implemented in 18 hill VDCs of Nawalparasi district. By the end of December 2008, Patta (lease) has been provided to 34 leasehold forest user groups with 2,621 populations to manage 300 ha of forest area. The LHF has been not only supporting for the livelihoods of poor ethnic communities but also retarding shifting cultivation practices resulting in reduced forest fires and soil erosion.

Religious Forestry: There are only six religious forests that cover an area of 114 ha within the three districts.
Buffer Zone Community Forest: In Nawalparasi district, six buffer zone CFs are formed, and they cover an area of 213.8 ha. These are managed primarily with a conservation objective.

Protection Forests: Like other Terai forest, a large portion of western Terai forest is found in the Siwalik Hills, (and even in Mahabharat range in Nawalparasi district). These forests along with some riverbank areas were classified as protection forest by OFMP, although no any other legal or policy documents explicitly describe about the protection forests. The protection forests by their category would have been managed for watershed protection and soil erosion control.

Private Forestry: There are 276 registered private forests, covering an area of 220.02 ha and many other unregistered private forests also exist in the western Terai.

\section{EMERGING DEMOCRATIC INNOVATIONS IN THE WESTERN TERAI}

With varying level of intervention and input from projects, stakeholders and sometimes by users themselves, several institutional innovations (though are in small scale) to contribute in resolving various issues at different level have emerged in Terai forest management. Figure 1 provides a brief overview of such innovations that are discussed below.

Figure 1: Emerging innovation in Terai forestry

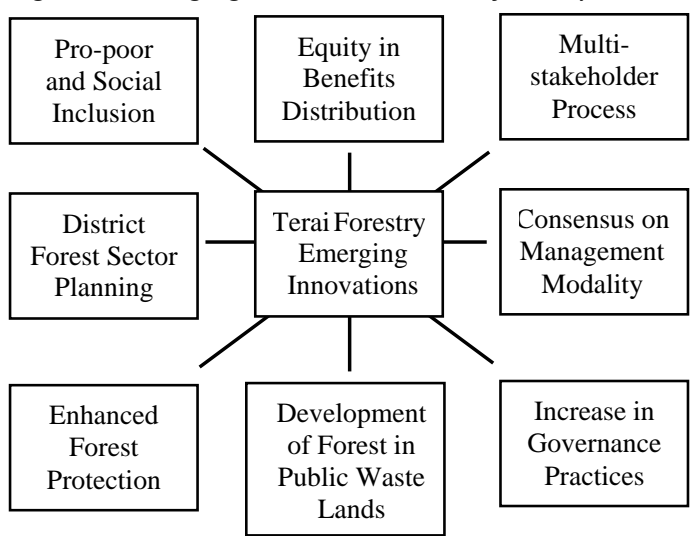




\section{Inclusion in Community Forestry}

Exclusion of the traditional users, especially the poor and marginalised, is a general issue raised by different stakeholders. Consequently, users have been addressing such issues gradually by identifying excluded households, and then including them in the CFUGs. Depending upon the well-being ranking of the households, CFUGs waive or provide concessions in the membership fee. In the three study districts, around 7,000 households were included into CFUGs between 2005-08 by amending CFUGs' constitution. Among the included households, more than 59 percent are from poor category and 65 percent are from disadvantaged, Dalit and religious minority groups. In some cases distant users have been included as secondary users. Charpala CFUG in Rupandehi demonstrates users' ability to manage large area of forest as CF with the accommodation of larger section of the community (Box 1).

\section{Box 1: Charpala as an example of inclusive CFUG}

Charpala is one of the biggest CFUG in Nepal both in terms of forest area occupied (1,558.25 ha) and the number of users ( 9600 households). Forest was handed over to the CFUG in 1997. It has a multitier council based system to elect its executive committee. It has 12 sub-committees including one each in its 7 VDCS namely: Semlar, Kha.Bangai, Sau Pharsatikar, Amuwa, Manpakadi, Manmateriya and Motipur and 5 sub-committees in Butawal Municipality (users in the vicinity). Each subcommittee consist of 13 elected members including; 1 elected members and 2 nominated members. One member from each sub-committee represents in main executive committee which has 156 council members. Once executive committee is formed, it forms advisory, account and other subcommittees as per need. According to the CFUG monitoring report, assembly is regular with 72 percent members participation, executive committee meetings are also regular (one each month), 5 of 19 executive members are female, 80 percent decisions made by committee are executed, manages annual budget of more than 11 lakhs and has been rated as good CFUG in the district.

\section{Equity in Benefits Distribution}

To address the issue of inequity within the CFUGs, users have initiated the provision and practice of equitable forest product distribution based on economic status of the households. Provision of free or minimum price in the distribution of forest products for the poor has been a common practice in the western Terai. Almost 5opercent of CFUGs have at least three equity provisions focused on the poor and excluded in their Operational Plan and 39percent of CFUGs have translated those provisions into practice.

CFUGs that were previously restrictive to distribute forest products to people outside their users' territory are now prepared for selling surplus forest products to their neighbouring southern VDCs. Instead of selling forest products outside the district or to the contractors, CFUGs (e.g. Kalika CFUG and Buddhanagar CFUG in Rupandehi) are giving priority to sell forest products to southern VDCs in subsidised rates.

In principle, proximate users receive most of the benefits from community forests while the distant users even within CFUG do not get adequate access to forest products. In order to benefit such distant users, CFUGs such as Charpala in Rupandehi district have established depot at the vicinity of distant users.

\section{Developing Forest Resources in Public Waste Land}

Since forests are confined to northern area (e.g. in Rupandehi almost half of the VDCs do not have any natural forests), public waste land management has been the alternative to contribute to capturing forestry, income generation and livelihood opportunities for the southern rural. By December 2008, around 5 percent ( $975.65 \mathrm{ha}$ ) of the total public lands (around 20,000 ha) available for management 
is being managed by 283 groups comprising of 25,000 households. Among these, with good regeneration of forest, a total of 30 public lands covering an area of 396.24 ha have been handed over as CF to 6,705 households in the three districts.

In Nawalparasi district, Federation of Community Forestry Users, Nepal (FECOFUN) has been working with DFO, to keep the provision and practice for allocating certain ${ }^{4}$ amount of budget from the northern CFUGs' earnings to support for natural resources generation (mainly for public land management) and community development in southern belt. This is incorporated in the DFSP. As part of implementation, a joint account between the FECOFUN and the DFO (represented by a staff) has been operated to collect such fund.

\section{Communities Proactive Efforts in Protecting National Forest}

Despite some set-back in CF handover after the 2000 policy, several communities have expressed their willingness to manage their nearby national forests as [proposed] CF by organising themselves into protection committee. Local people continue with their conservation activities. Such proposed CFs and/or potential CFs include CFUGs of different status, such as: a) registered at the DFO but forests not handed over, i.e. operational plans are not approved, b) protection committees formed $a d-h o c$ and not registered, c) groups are just protecting the forest with the hope of obtaining $\mathrm{CF}$, and d) groups that have already got the CF but are also protecting national forest in their vicinity with the hope to extend their CF area. In December 2008, altogether 104 user groups were found registered and 108 unregistered in the three districts, in which 66,825 households are involved as users in managing approximately 18,000 ha of forests (LFP 2008).

\section{Local Level Multi-stakeholder Forum for Democratic Dialogue}

District Forest Coordination Committees, as a multi-stakeholder forum are established according to the DFCC guidelines. The DFCCs were formed under the article 190 of the Local Self Government Act (LSGA) 1998. After MFSC issued the DFCC guidelines 2005, the DFCCS were restructured and were replicated in other donor funded programme districts. The DFCC has become an instrument for good forest governance through deliberative and participative processes, leading to empowerment, ownership and commitment to sustainable forest management (Rana et al. 2008).

So far DFCC meetings have played crucial role in improving forest governance coordination for planning, monitoring, implementation and review of forestry sector programme. Preparation of DFSP and joint monitoring practices are major achievements of the DFCC. It is useful to bring conflicting parties into negotiation. The forum has sustained even under political uncertainty and conflict situation of the recent past. The DFCC has encouraged District Development Committees to contribute to forestry sector. At times, the fora have also been active to evacuate encroached forest areas.

At the local level, various multi-stakeholder networks and fora have emerged. These include Village Forest Coordination Committee, Village Level Forest User Groups Network and Cluster Level Coordination Committees. Most of these are based on political boundaries but some are formed across the district. Cross-district coordination committee has emerged at least in a token scale among CFUGs in Butwal Municipality in Rupandehi and their peer groups in adjoining Palpa district. They coordinate in forest protection and in development programme. 


\section{Multi-stakeholder Deliberation on Forestry Visioning}

Controversy among various stakeholders over forest management modalities especially after the year $\mathbf{2 0 0 0}$ is a major concern of sustainable forest management in the Terai. To resolve the issue, multi-stakeholder debate and consensus have been initiated in the study districts through District Forestry Sector Plan (DFSP), which is a strategic document envisioning forestry sector development at district level. Unlike an operational or management plan of a particular forest patch, DFSP is a broader and longer-term plan encompassing a wider horizon of district forestry sector including political, social, economic and environmental aspects of forestry beyond its technical and management scope (Box 2). The current three-year Interim Plan has given priority for the preparation and implementation of DFSP for district level forest visioning.

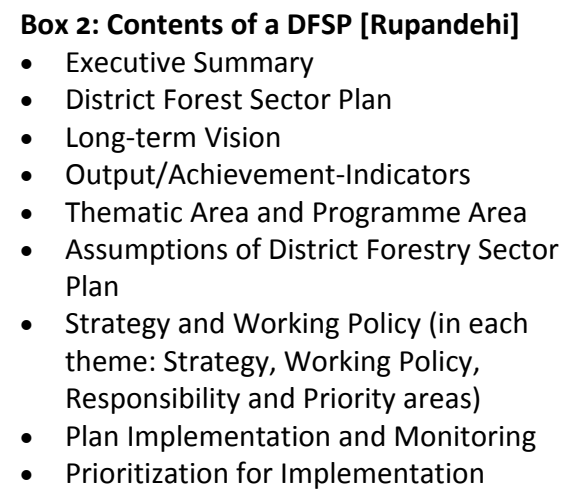

- Strategy and Working Policy (in each theme: Strategy, Working Policy, Responsibility and Priority areas)

- Plan Implementation and Monitoring

- Prioritization for Implementation

There are various key features of consultative DFSPs that have been prepared in the study districts. These include a) common voice, ownership and commitment from stakeholders, including the political parties; b) inclusive in terms of needs and aspiration of poor and excluded, including southern Terai population; c) mapping of different participatory forest management modalities; d) linkage and coordination within district periodic plan, DFSP and DFO five-year plan; e) bottom up and wider planning approach through multi-stakeholder involvement; f) recognition of stakeholders and their role in resource management; and g) recognition of local authority and DFCC.

\section{ISSUES AND IMPLICATIONS}

\section{Diversity Context Demands Equitable Policy Responses}

It is evident that government considered Terai forest as a high-value resource in order to generate revenue and to meet increasing national demand of forest products. Government decisions to suspend community forestry, taxation policies, ban on green tree felling and initiation of collaborative forest management reflect that government wants to retain valuable and productive forests of Terai under its own control despite handing over to communities as CF in some places. In doing so, government has failed to consider the equity concern amongst stakeholders given the diverse context of Terai forestry (Box 3).

\section{Box 3: Diversity in Terai forestry context}

Terai is different and complex than hill areas of Nepal in geographical, social, cultural and political settings. Even within forestry, there exists diversity in CFs such as on types of forest (natural and plantation), land authority/tenure (CF in National forest and CF in public land), forest management (active and passive), topography (plain, Siwalik and foot hills of Mahabharat). Based on resource condition, CFUGs in Rupandehi district are of 4 basic categories viz. Rich (13 percnet), Medium (29 percent), Poor (34 percent) and Very Poor (24 percent). Similarly, out of total 65 CF handed over in district, 26 are in public lands. Charpala is the largest CF with an area of 1,558.25 ha, whereas there are CFs especially those from public land which are less than 5 ha. CFs handed over in national forest areas are mostly plantations and are degraded even if these are natural forests. This situation clearly demonstrates diversity in CF and the generic perception that the Terai CFs are very rich is not true as such. Therefore, the recognition of the diversity and the requirement for equitable policy treatment is clear. 
More recently, the government considered the issue of inclusion of distant users by introducing CFM. However, it failed to address the contextspecific forest management initiatives that flourished at the grass root level. There are several cases of injustice incurred to CFUGs due to generic policy prescriptions such as ban on green tree felling and restriction in forest handover etc. In addition, government's initiative to control wrong-doing in CFUGs results in negative consequences for CFUGs that are functioning well. In addition, there are proposed CFs, some of which are genuine to be handed over. Some other CFUGs can be reshuffled to make them more inclusive or to convert into other management modality like CFM. Box 4 shows how they are functioning like formal CFUGs.

\begin{abstract}
Box 4: Proposed CFUGs and their functioning
Proposed CFs have been protected by their users in a better way than GMF though these are poorer in quality than handed over CFs. Different ways of forest protection has been applied including employing watchers or patrolling by group members. Riverbank protection and plantation are their other forestry activities. The proposed CFUGs have also pressurised the DFOs to hand-over the forest as CF in different ways (such as in a threatening language as they will deteriorate the forest if not handed over, padlocking DFO office etc.). During conflict period, some proposed CFUGs were also found cultivating paddy in the forest area.

Proposed CFUGs do not have their approved OP and constitution to guide their activities. However, many of them are honestly protecting these forests and collecting 3D (dead, dying and diseased) trees and distributing among themselves. However, the prices of forest products are far lower than those at other CFUG and local market, which would lead to higher hidden subsidy [to rich groups who use timber] than that of handed over CF. Their activities are not reported ${ }^{5}$ in DFO or other organisations. This makes them maintain their transaction opaque, and may lead to the misuse of their fund. There are informal understandings to collect forest products between DFO and users which is both positive and negative. Some community leaders shared that the misuse and corruption is so deep rooted that some of the proposed CFUGs do not want the DFO to handover their proposed CF. Though poverty reduction activities are not found, some of such CFUGs are doing well in forest management and community development activities.
\end{abstract}

\section{Defining Forest Management Modalities}

Top-down approach to defining forest management modalities has, by and large, hindered the pace of managing Terai forests. Task Force on Democratising Forestry Sector of Nepal (2007) recommended that district level stakeholders be given authority to decide on selecting management modalities suitable to their forests in the district instead of dictating from the centre. Although community-based management have been the agreed modalities, they have also a number of further categorisation depending on objectives of management, level of people's participation, pattern of cost-benefit distribution and decision-making authority. Existing community- based forest management modalities include community forests, buffer zone community forestry, collaborative forest management, leasehold forestry and religious forestry (Ojha et al. 2007). Among these, CF is a pioneer participatory model and has a comparatively long history. Other management modalities including CFM seem to have come as a way of addressing some of the limitations which CF faced in practice. CFM emerged in early 2000s, when the limitations of CF, such as elite domination in decision-making, inequity in benefit sharing, and lack of linkage with local government, became more visible (Ojha et al. 2007). However, each of the participatory modalities have some areas to improve on one hand while, each has unique relevance on the other. Different studies show that both CF and 
CFM have their strengths as well as weaknesses (Bampton and Cammaert 2006, Bampton et al. 2004, Ebregt et al. 2007, Kanel et al. 2005, Kanel et al. 2003, Ojha 2008, Ojha et al. 2007).

Incorporation of both CF and CFM in DFSP has made it apparent that there is scope for each modality to be put into practice. Though CFM is in its early stage and needs practical demonstration and refinement with respect to cost and benefit sharing in order to prove its rationale, it has been established as an option for sustainable forest management, and ignoring it would be undemocratic (Ojha 2008). Though the multi-stakeholder processes have succeeded to bring stakeholders in an agreement for mapping different forest management modalities during preparation of DFSP, there could be several practical challenges while delineating CF and CFM mainly in the areas where there are already proposed CFs. Decisions could be violated if nearby users could not get equitable share in resource allocation.

Regarding new innovation in public land, Kunwar et al. (2007) demonstrates that its effective management provides an important asset for communities to generate forest resources, to reduce vulnerability, and to generate livelihood opportunities for the landless and land-poor. These are developed as forest management modality for areas where public lands exist provided that policy provisions are made clear. In addition, there is scope for a viable forestry sector enriched with handsome revenue from scientific management of remaining GMF and with negotiated and equitable revenue from community-based forest management.

\section{Need for Effective Implementation of District Forest Sector Plan}

District Forest Sector Plan has emerged as a good practice for the forestry sector in the districts. However, there is still confusion whether it is necessary to approve DFSPs from the MFSC or can it be put to work after the approval from the DFCC/DDC council. In current practice (as in BISEP-ST districts) the DFSPs have been effective only after its approval from the
MFSC. It has induced higher level of bureaucratic uncertainties in approval process. In order to be effective, DFSP should not remain in a form of document but has to be implemented properly. Active leadership by the concerned DFO/DFCC and effective communication and dissemination to grassroots stakeholders are crucial. It is also of concern how the central government responds to these plans in order to get DFSP implemented successfully.

\section{Contradiction and Instability in Government Policies and Decisions}

Government's forestry policies exhibit contradiction and instability (Box 5). Although the Forest Act 1993 and Forest Regulation 1995 do not discriminate geographic belts for any forest management modality, some other policy documents show a bias towards some specific modalities of forest management in specific belts (Dhungana 2007). There exists contradiction amongst Master Plan (focus on hill) and Forest Act (focus on whole country) on promoting $\mathrm{CF}$ in the Terai. Similarly, contradictions exist between the Forest Act 1993 and the Local Self Governance Act 1999 on such crucial aspects as the ownership and management control of the local forest, formation of DFCC, and revenue sharing. The Revised Forest Policy $\mathbf{2 0 0 0}$ has further fuelled conflict on Terai forest management. It is found that the government's subsequent policies, statements, circulars and directives have undermined the thrust of Forest Act 1993. In some cases, such as the taxation in $\mathrm{CF}$, revenue sharing in CFM, suspending handover of $\mathrm{CF}$, the government decisions seemed immature as they were frequently changed due to pressure from different forestry stakeholders. All these contradiction and instability exert pressure to DFO both from central policy and grass root level stakeholders. To reduce the contradiction and instability of the policies and decisions, policy-making needs to be made inclusive and participatory. This will increase the ownership of the stakeholders and open up the avenues for innovations and provide flexibility in implementing the programmes. 
Box 5: Instability in government decision

On $30^{\text {th }}$ June 2006, a ten-point agreement between the MFSC and FECOFUN was made in which, a point stated that the CFM guideline 2003 and the DFCC Management and Operation Directive 2005 would be nullified and the pilot plots of CFM would be converted to 'model CF'. The decision resulted into a counter protest from CFM users and some politicians of the Madhesi origin. The protesters argued that $\mathrm{CF}$ in the Terai is not inclusive enough to include southern distant users, especially the Madhesi people. They argued that CFM was the first ever programme to address the issues of southern distant users. Consequently, on $16^{\text {th }}$ July 2006 the Ministry has withdrawn its earlier decision and reinstated the Ministry's agreement to continue CFM coupled with the revitalisation of CFM Guidelines and DFCC Directive 2005 with a further step that CFM Regulation would be formulated.

Source: Bampton et al. 2007 and Dhungana 2007

\section{Institutional Mechanisms for Allocating Funds and Forest Products to Southern Terai}

The CFUGs' provision for allocation of certain percentage of income to the people of southern belt for natural resource generation is a good initiative but there are still challenges in effectively and sustainably translating such practice into action. So far the funds and forest products are provided to the southern Terai population on the basis of ad hoc decision between district level CF users' federation and DFO. However, it has been questioned since it is not supported by the policy. Without policy, implementing such action might be difficult for CFUGs to decide through their general assemblies. There is a risk to respect the decision of the federation by individual CFUGs. A clear guideline is required so as to determine the questions such as where and how to invest, who will decide on fund allocation, and the prioritisation of fund use.

\section{Representation and Legitimacy in Multi-stakeholder Forum}

The DFCC as multi-stakeholder forums have their own issues and limitations due to difficulties in organising meetings timely, complexities in reaching a consensus, eliminating elite and political influence, and ensuring proper and consistent representations from the institutions. Effectiveness of such forums relies highly on their leadership and capable and active representation of their members. Legitimacy of the forums and their decision depends on their mandate. As per the DFCC guideline, it has decision-making power, but in practice it serves as an advisory body only. How there decisions are respected by concerned organisations, including central bodies such as MFSC, are other concerns.

Active and effective participation of members in the multi-stakeholder forums needs more exercises. The horizontal and vertical linkage amongst the forums at different levels (village, regional, district and national) is equally necessary for better coordination. Institutionalisation of joint monitoring practices, balancing district level planning with that of landscape level planning and village level planning are other issues that need further attention.

\section{Linking Community Management of Forest with Local Government}

Collaborative Forest Management ensures a strong link on community management of forest with local government but such link between CFUGs and the local government is still at early stage and weak. There is frequently an unfair competition between CFUGs and VDCs due to an imbalance of power between them. Generally the CFUGs have huge financial resources while VDCs have great political, administrative and other residual power as local government. Therefore, further efforts are needed to facilitate a smooth relation and cooperation between these two institutions. 


\section{Improvements, Institutionalisation and Replication of Innovation}

Various innovations, that have emerged locally, require regular monitoring and replication with improvement and institutionalisation. Practices aimed at inclusiveness, equitable distribution and local level multi-stakeholder process require expansion to other areas. However, it is not necessary that all innovations can be replicated in blanket approach but their specific context should be well considered. Further, new innovations need to be continually pursued at various levels.

\section{CONCLUSION}

In Nepal, Terai forest management continues to be highly contested. A large segment of the Terai forest is under government control, lacks management interventions, and suffers from deforestation and degradation. Despite several policy endeavours, the government has failed to harness the enormous potential that lies in Terai forest. Instead, it is confronting conflicts among stakeholders and is hit with poor governance. This may largely be attributed to government's tendency to enforce top-down approach in policy and planning, and for its inability to fully understand the complexity of Terai forest management.

Recently, however, several innovations especially on institutional mechanisms and deliberative processes have emerged at different scales in the Terai. With the adoption of multi-stakeholder processes at district and village levels, opportunities for participation and open dialogue have increased, which improved the cooperation and collaboration among stakeholders. Several stakeholders are now involved in participatory forest management planning, joint monitoring and reviews. Multistakeholder dialogues on forest management also helped resolve disputes on diverging forest management modalities. This process has the potential to reconcile conflicting demands of resource sharing amongst the populations of northern and southern parts of Terai.
Despite certain mutual suspicion and frustrations over their legacy and mandate, forestry stakeholders in the three western Terai districts have actively participated in the bottom up planning process for developing the DFSP. The DFSP process has captured most of the local level innovations and has determined the forest management modality that would suit to specific contexts. This approach helps develop a viable forestry sector enriched with revenue from government forests and with equitable benefit distribution under community management. Similarly, active leadership of forestry authority and stakeholder ownership over forestry programmes define the success of DFSP implementation.

The innovations on inclusiveness and equitable practices in CFUGs have provided access of the poor and excluded groups and distant users to forest resources as well as financial resources. Similarly, promotion of resource management in public land is effective to address some forestry issues in the Terai. Further, the financial support of CFUGs for resource management in the southern Terai is a good incentive for the people in the area. Overall, we conclude that a decentralised and multi-stakeholder planning process, backed by a genuine commitment from the government, has the potential to produce forest management schemes and plans that work to benefit both the local people and central government.

\section{REFERENCES}

Bampton J.F.R. \& Cammaert, B. 2007. How Can Timber Rents Better Contribute to Poverty Reduction through Community Forestry in the Terai Region of Nepal. Journal of Forest and Livelihoods, 6(1): 28-47.

Bampton, J.F.R. 2006. LFP and Forest Management in Terai Sabaika Ankha Pareko Teraika Ban (Terai Forests viewed from all eyes). Prakritik Sampada (Natural Resources), 2(4): 5457.

Bampton, J.F.R., Ebregt, A. \& Banjade, M. 2007. Collaborative Forest Management in Nepal's Terai: Policy Practice and Contestation. Journal of Forest and Livelihood, 6(2): 30-43. 
Bampton, J.F.R., Vickers, B., Rana, B. \& Statz, J. 2004. Community Forestry in the Terai Region of Nepal. In: K.R. Kanel, P. Mathema, B.R. Kandel, D.R. Niraula, A.R. Sharma and M. Gautam (Eds.), Twenty five Years of Community Foresty: Proceedings of the Fourth National Workshop on Community Forestry. Kathmandu: Community Forestry Division, Department of Forest.

Baral, J.C. 2002. Depleting Forests, Silent Spectators: Who Should Manage Nepal's Terai Forest? Journal of Forest and Livelihood, 2(1): 34-40.

CBS 2005. Statistical Year Book of Nepal. Kathmandu: Central Bureau of Statistics, His Majesty's Government of Nepal.

Dhungana, S. 2007. Forest Management in Terai: Revisiting contests, processes and Issues, Environment and Resource Institute (ERI).

Ebregt, A., Paudyal, D., Sah, R.N., Siwakoti, R.S. \& Thapa, Y.B. 2007. Collaborative Forest Management in Nepal (Challenges and Prospects). Kathmandu: GoN, MFSC, BISEP-ST, Nepal

Kanel, K.R., Nepal, S.M. \& Sharma A 2003. Terai Arc: Institutions, Incentives and Forest Management (assessment of forest management modes in TAL Districts of Nepal). Kathmandu: WWF Nepal.

Kanel, K.R., Poudyal, R.P \& Baral, J.P 2005. Nepal Community Forestry 2005. Available at: http://www.recoftc.org/site/fileadmin/docs/pu blications/The Grey Zone/2006/CF Forum/pol icy_nepal.pdf

Kunwar, M., Neil, P., Paudyal, B.R. \& Subedi, R. 2008. Securing Rights to livelihoods through Public Land Management: Opportunities and
Challenges. Journal of Forest and Livelihood, 7(1): 70-86.

LFP 2008. An Overview of Terai Forestry in Three LFP Districts. Bhairahawa: Livelihoods and Forestry Programme (Final Draft), Terai Coordination Office.

Ojha, H.R. 2008. Transforming Nepal's Terai Forest Governance: A Policy Perspective - Policy Discussion Note. Kathmandu: Forest Action Nepal.

Ojha, H.R., Timsina, N.P., Kumar, C., Belcher, B. \& Banjade, M.R. 2007. Community-based Forest Management Programmes in Nepal: An Overview of Issues and Lessons. Journal of Forest and Livelihood, 6(2): 1-7.

Pokharel, B., Branney, P., Mike, N. \& Malla, Y.B 2007. Community Forestry: Conserving Forests, Sustaining Livelihoods and Strengthening Democracy. Journal of Forest and Livelihood, 6(2): 8-19.

Pravat, P.S. 2006. A History of Forest Politics in the Terai, Nepal: A Case of Equity or Ecology, Paper prepared for the ECPR Summer School on Environmental Politica, Keele University, June 26th-July 7th 2006.

Rai, R.K. 2007. Nepal's Terai Forest Management: an Ethical View. Paper submitted for Seminar at University of Joensuu, Finland. Available at: http://www.forestrynepal.org/images/publicati ons/TeraiForestManagemetnEthicalView.pdf

Rana, B., Khanal, K.P. \& Kotru, R. 2008. Multistakeholders Process for Decentralized Governance: Lessons from District Forest Coordination Committees in Terai Districts, $A$ Paper Presented in Fifth National Community Forestry Workshop, Kathmandu.

\footnotetext{
1 It was a project focusing intensively on harvesting of natural forests followed by massive plantation of fast growing species, such as Eucalyptus and Sissoo.

2 Especially when it requires felling of green tree which is banned by the government

3 A Tilaurakot CFM group constitution has been approved and a task force has been formed to outline management plan by a general assembly in Kapilvastu district. Three groups with management plan are planned for this fiscal year which includes one each in 3 study districts.

4 Verbally $5 \%$ agreed as the minimum amount.

5 Respondent from proposed CFUGs either hesitant to provide detail information or requested not to mention their name in the paper.
} 